\title{
EL EMPRESARIADO \\ EN UN RÉGIMEN SOCIALISTA: \\ EL CASO VENEZUELA
}

ALEJANDRO JOSÉ MORILLO FERRER

Este análisis ha sido escrito como contribución a mi país, proponiendo al empresario venezolano algunas acciones, las cuales elaboro como si lanzara una botella desde una isla solitaria, preguntándome al final de cuentas sino es mi propio país el náufrago.

Tras constatar y participar en los avatares de la población venezolana, detecto con tristeza la imposibilidad de que Venezuela pueda avanzar hacia un desarrollo verdadero ni aún después del régimen impuesto por Hugo Chávez (actual Presidente), si la sociedad no ejecuta algún tipo de acción por sí misma. Es en este sentido que va mi propuesta.

\section{I \\ EL SOCIALISMO Y EL ESTADO COMUNAL}

Nuestro país ha vivido desde los años treinta del siglo pasado un intervencionismo estatal que ha sido caldo de cultivo para el socialismo que se viene tratando de imponer. Después de haber funcionado tanto tiempo un Estado interventor sobre una sociedad permisiva de tal acción, ha surgido un grupo de poder que lleva doce años actuando con ansias totalitarias bajo el concepto de «Estado Comunal».

El Estado Comunal no es el final del camino sino el camino mismo. Se trata de implantar un «sistema centralizado de planificación» a través del cual se asignan competencias y distribuyen recursos. Al respecto, ya en febrero del año 2010 se constituyó en Venezuela el Consejo Federal de Gobierno, presidido por el Vicepresidente e integrado por ministros, gobernadores, alcaldes y 
representantes populares con el fin de aplicar un «Plan de Inversiones» que recoge las peticiones de los consejos comunales, comunas y frentes populares y sus propuestas, de acuerdo a los lineamientos centrales de política. Pero toda esta estructura, sin base conceptual sólida, no nos dice: ¿qué es lo que se va a construir?, ¿cuál es el contenido de esa sociedad comunal?, ¿qué bienes y servicios va a producir, cómo y dónde?

El 13/12/2010 fue aprobada por la Asamblea Nacional la Ley Orgánica del Sistema Económico Comunal, la cual asienta las bases jurídicas del régimen de propiedad colectiva. A partir de esta ley, los grupos podrán organizarse en empresas de propiedad social directa comunal, unidad productiva familiar, y grupos de intercambio solidario. ¿Qué bienes de capital (fábricas, maquinarias) podrán producir estas organizaciones familiares y comunales? ¿Cómo se van a distribuir los recursos financieros para que funcione tal sistema en sus bases, bajo el entendido que no generará beneficios (ganancias) individuales, abajo en la masa, aunque si arriba, en la cúpula, como ya lo estamos viendo desde hace doce años? ¿Quién va a concebir ese sistema racionalmente organizado? ¿A partir de cuál información se va a diseñar un sistema de producción de bienes y servicios que abastezca a esas comunas de ensueño?

Si la sociedad es el resultado de la interacción de millones de seres humanos actuando cada uno según sus circunstancias, buscando cada quien mejorar su situación personal y familiar, ¿quién va ser capaz de pensar todo ese proceso constante, que nunca se detiene, para «ordenarlo» y «dirigirlo» hacia un «bien común» inimaginable? Vivimos un mundo cruzado de información digitalizada, de mercados que intercambian productos de refinada tecnología, de capitales que viajan como la luz para activar empresas encadenadas entre diferentes países en procesos productivos complejos y dinámicos. Paralelo a este mundo móvil se pretende constituir hoy en Venezuela un sistema social con mercados de trueques, monedas comunales y asambleas vociferantes que producirán hasta donde los delimite la autoridad úni$\mathrm{ca}$, sin beneficios personales ni ganancias de ningún tipo, viendo pasar el tren del progreso civilizatorio pleno de oportunidades individuales. 
Tal Estado Comunal no es más que una estructura de dominación centralizada al estilo de un gran feudo, donde cada quien ha de ocupar el lugar y la función que se le asigne. Este Estado funcionaría y se está implementando paralelo al Estado tradicional. $¿$ Es posible imaginar que tal aparato comunal sea viable, es decir, pueda desarrollarse a un lado del mercado de bienes y servicios que aún sobrevive y sobrevivirá, aunque sea con 80 o $90 \%$ de importación?

Es necesario reconocer que el Estado Comunal es una perversión del Estado Social. Y esto es así porque la Constitución del 1961 era y fue caldo de cultivo para la del 1999 y ésta para la pesadilla actual del Socialismo Siglo XXI.

\section{II EL ENFOQUE ENDÓGENO}

El desarrollo comunal pudiera ser abordado, con el enfoque endógeno, como un avance del desarrollo local. Desde los años sesenta, en Venezuela, los programas sociales locales de desarrollo buscan que las propias comunidades asuman el protagonismo de su desarrollo. Pero el intervencionismo estatal del Estado Social interfirió en tales programas. Las propias autoridades implicadas (gobernadores y alcaldes) imponían a las oficinas ejecutoras de los programas un acento político, de acuerdo al partido de turno en el gobierno (AD o COPEI) y luego, los propios promotores locales (personal encargado de ejecutar los programas) se topaban con una población sometida al paternalismo político que les hacía razonar bajo la premisa «ipor qué voy a construir algo si me lo regalan?». Y todo esto, además, se producía en un entorno donde el Estado construía y mantenía vías, hospitales, industrias básicas y hoteleras, además de financiar empresarios con créditos blandos e infinitos. En tal ambiente, por supuesto, no era posible demostrar a las poblaciones locales las ventajas de un desarrollo a partir de si mismos y no del Estado protector.

$\mathrm{Al}$ inicio, el régimen pretendió aplicar el concepto de desarrollo endógeno, pero en cambio, implantó un Consejo Federal de Gobierno que impone criterios políticos para aceptar proyectos 
locales y darles recursos financieros, donde prevalece el enfoque del voluntarismo rechazando la tendencia humana a buscar individualmente el beneficio individual y familiar, se actúa contra el concepto endógeno mismo y contra la naturaleza humana.

Imaginemos por un instante que el régimen actual se desmorona y cae. ¿Qué ocurriría con nuestras comunidades? He aquí un verdadero desafío para el cual debemos estar preparados, so pena de repetir errores viejos o cometer nuevos disparates como el actual. Porque, aún desapareciendo la perversión socialista, no hay que olvidar que el Estado Social protector y paternalista continúa y continuará haciendo lo que ya venía haciendo y que dio justamente lugar a esta perversión.

Tomando el principio básico de que la empresa privada es la que produce bienestar en toda sociedad y no el Estado, es oportuno revisar el desarrollo industrial con la óptica liberal del desarrollo endógeno. Si bien toda empresa tiene que estar inmersa en mercados nacionales e internacionales, ello no niega que ella está inserta territorial y socialmente en la comunidad donde recluta, selecciona y forma personal para ejecutar todas las tareas que exige su producción. Y esta vinculación es clave para ejercer un liderazgo. Esto lo han intentado desde mitad del siglo pasado algunas grandes empresas venezolanas, para lo cual establecen fundaciones con personal técnico que desarrolle programas sociales en comunidades vecinas a la localización de sus inversiones, pero, lamentablemente, esta acción empresarial no ha logrado sacudirse la visión asistencialista que impera y le llega como modelo del Estado Social, lo cual demuestra que este Estado Benefactor se cuela en toda la sociedad, llegando a frenar en esta su tendencia natural a la acción emprendedora.

El desarrollo endógeno no implica Estado Comunal ni Estado Social, por el contrario, la utilización por las poblaciones locales, de sus propias fuerzas en un ambiente empresarial, justamente detendría en parte la intervención estatal y su proteccionismo. El problema real a resolver está en la conciencia estatista de las poblaciones y en su dependencia del Estado hecha ya costumbre. Para romper este paradigma, indudablemente, hace falta un estímulo fuerte que no puede venir más que de las empresas privadas, no 
sólo por la necesidad de recursos financieros y técnicos, sino, sobre todo, por el carácter liberal que han de asumir las acciones a desarrollar dentro de la comunidad.

Tampoco se trata de que la empresa privada sustituya al Estado actuando como agente externo. Primero, ello no es posible conceptualmente, porque el sentido de la acción empresarial es diametralmente opuesto al de la acción estatal y luego porque se trata de fortalecer los vínculos empresa-comunidad como actores de un mismo espacio social.

Manuel Castel ${ }^{1}$ ha destacado la necesidad de aprovechar la oportunidad que brindan las transformaciones mundiales para impulsar lo que ha denominado un desarrollo endógeno globalizado que incorpore la cultura de la sostenibilidad y la exigencia de la cohesión social. Para él, la capacidad tecnológica de la empresa es esencial para producir en una economía globalizada, pero el aprovechamiento de esta capacidad requiere una reorganización para funcionar en red. Ha puntualizado también que la fuente más importante de la productividad es la innovación de procesos y productos, no la tecnológica, y ha subrayado que no hay sectores innovadores, sino procesos innovadores en todos los sectores. La fuente de la innovación, en opinión de Manuel Castells, es el emprendimiento, basado en una cultura del emprendimiento y el desarrollo del sistema educativo.

De estos señalamientos de Castells se desprende que el proceso de innovación implica a toda la sociedad y que sin el emprendimiento como cultura no puede haber innovación. No es necesario organizar ninguna red con respecto a la capacidad tecnológica, ella surge de manera natural a través del mercado. Un desarrollo endógeno en plena globalización, sin embargo, sin ser tema de este análisis, me remite a lo que en cibernética se denomina recursividad, según lo cual, todo sistema contiene y está contenido por otro

${ }^{1}$ Conferencia de Manuel Castells, catedrático emérito de Planificación Regional de la Universidad de California-Berkeley en Baluarte, con el título «Innovación, competitividad y nuevas tecnologías», organizada por el Gobierno de Navarra y Sodena en el marco del II Plan de Promoción de la Sociedad de la Información y las Telecomunicaciones en la Comunidad Foral de Navarra. (01/03/2005). http:/ /www. sodena.com/cas/pdf-word/CASTELLS.pdf 
sistema. ${ }^{2}$ Si tomamos una comunidad donde esté localizada una empresa mediana o grande, encontraremos que el conjunto tiene casi siempre características de sistema y que, justamente, en la medida en la cual se involucren ambas instancias - la comunidad y la empresa (s) - en un sistema de innovación tecnológica orientado por el mercado, en esa medida ese sistema social podrá crear un propósito productivo que sirva de identificación y pertenencia a toda la población, bien se trate de una industria extractiva de mineral o explotadora de madera, propósito que no está previamente escrito en ninguna parte ni pensado por nadie, sino que surgirá del quehacer productivo predominante en la población, quehacer que puede llegar a especializar a ese sistema social en un bien o servicio preponderante que le permitirá, a través del mercado, lograr los otros bienes y servicios que alimenten su calidad de vida.

En el sector manufacturero, en el metalmecánico, el textil, el hotelero, telecomunicaciones, envases, transporte y hasta el siderúrgico venezolanos entre otros ocurrió hasta 1998 un crecimiento empresarial, pero el hecho mismo de que FEDECÁMARAS, ${ }^{3}$ como representante de sus gremios, no tuviera la suficiente fuerza para paralizar realmente el aparato productivo en el Paro Cívico desarrollado de diciembre de 2002 a febrero de 2003 (a pesar, incluso, de actuar en coalición con la Confederación de Trabajadores de Venezuela), indica que el Estado ha sido y es el centro desde donde se interviene toda la dinámica social, minimizando y aplastando cada vez más la iniciativa privada.

La arremetida del régimen actual contra la empresa privada, sin embargo, ha llegado a colocar ésta en el centro de un debate donde nunca tuvo la oportunidad de estar. Por paradójico que parezca, nunca antes el empresariado había tenido tanto centimetraje de prensa como ahora. Y si bien el régimen siempre pretendió y pretende desacreditarlo, el empresariado ha terminado jugando el papel de víctima de un desastre palpable. ¿Qué mejor

${ }^{2} \mathrm{Al}$ respecto sugiero el manejo que hacen de principios de la cibernética como equifinalidad, recursividad, homeóstasis, entropía, variedad, etc. autores clásicos como Stafford Beer y W. Ross Ashby.

${ }^{3}$ Federación de Cámaras y Asociaciones de Comercio y Producción de Venezuela. 
oportunidad tiene este empresariado que ésta para comenzar a vincularse de otra manera con la población? Por supuesto que me refiero a una vinculación concreta dentro de los espacios sociales y no a través de los medios de información y/o la propia FEDECÁMARAS.

Lo mejor del calificativo endógeno es que permite trabajar dentro del concepto de sistema, entendiendo por tal cualquier cosa compuesta por partes o elementos que se relacionan e interactúan entre sí, donde es importante asumir sus límites de acuerdo a su naturaleza y propósitos. No es lo mismo referirse a un sistema social en una región o localidad minera, que una agrícola o manufacturera y aún entre regiones, localidades o sistemas de una misma naturaleza productiva, la interacción cambia porque cambia el drama social cotidiano, porque son historias diferentes, porque el quehacer humano empresarial, sea cual sea su naturaleza (primaria. secundaria o terciaria, de bienes o servicios, etc.), es irrepetible en su creación de información, porque la dinámica de los mercados es infinitamente diversa también de acuerdo a la naturaleza de los sistemas, porque el ajuste natural entre los actores económicos depende de los dos anteriores.

Lo importante en esa nueva vinculación que propongo es que no haya intervención del Estado y que éste - cuando exista uno respetuoso de las libertades- se dedique a cuidar que el marco jurídico legal sea igual para todos los ciudadanos, no importa su condición, con lo cual se tiene que eliminar de las motivaciones legales la perniciosa justicia social que tanto daño ha hecho al progreso civilizatorio.

Es verdad que, como lo tomábamos de Manuel Castells antes, la capacidad tecnológica requiere una reorganización, en este caso social. Pero esta reorganización no tiene que ser "pensada» por nadie, ella ha de producirse al reajustarse entre si los actores, desde el pequeño tendero que descubre el valor económico de un producto viejo o nuevo pero de gran demanda, hasta un gran industrial que cambia el formato de su producción porque intuye un nuevo uso, pasando por un joven que crea en el garaje de sus padres una nueva tecnología para el cambio de aceite automotor. 


\section{III EL EMPRENDIMIENTO COMO CULTURA}

¿Cómo asumir el emprendimiento como cultura? ¿Cómo lograr que nuestra población asuma este valor? La cultura impuesta por el Estado no se corresponde con el actuar humano, si no que lo coarta. Lo que ocurre es que estamos acostumbrados al camino hecho por el Estado. Ante cada problema o situación que enfrentamos, pedimos la intervención del gobierno. Para cada problema social, económico o cultural se presenta y hasta se exige un Plan; y cada Plan supone y requiere una oficina que se encargue de diseñarlo, otra de llevarlo a cabo y hasta una más para reformarlo, aunque esto último paso generalmente se le asigna a una Comisión. Y como ya entonces el problema se ha institucionalizado, es decir, que existe gente empleada en enfrentarlo, entonces ello asegura que el problema continuará existiendo porque la estructura burocrática creada para atenderlo lo justifica y hasta se agravará, por el sencillo hecho de que la dinámica social es inatrapable.

¿Cómo es eso de que la dinámica social es inatrapable? Acá reside el más grave error de origen del socialismo y el intervencionismo estatal. En una actitud arrogante, el gobernante o digamos el aspirante a tal, promete conducir la sociedad hacia un estado de bienestar total, para lo cual presenta un Programa de Gobierno, programa que luego, ya en el poder, dará lugar a un Plan de la Nación. ¿Y cuál es el origen de tal Plan, aparte de la ideología de sus autores? R: El diagnóstico, esto es, la fotografía de lo que está pasando. Sin embargo, después de realizarse el diagnóstico, las cosas siguen sucediendo, o sea, el fenómeno continúa su desarrollo, de manera que, cuando las autoridades actúan, los eventos han cambiado, han mutado como los virus y la vacuna ya es inocua, por ello los textos mas conspicuos sobre el tema reconocen las funciones internas que cumple la planificación dentro de la organización, tal como Bolman y Deal ${ }^{4}$ cuando presentan cuatro interpretaciones de los procesos organizacionales. ${ }^{5}$ Se observa

\footnotetext{
4 Bolman y Deal, (1995).

5 Bolman y Deal le atribuyen a la Planificación funciones como estas: desde el punto de vista estructural, como estrategias para definir objetivos y coordinar recursos;
} 
así que la planificación tiene una gran utilidad interna a la organización que la lleva adelante en términos de coordinación, de unidad, de redistribución del poder, como ritual simbólico y como referencia para negociar. Esto, cuando se trata de organizaciones, pero ¿qué ocurre en la realidad cuando se pretende elaborar y ejecutar un Plan Nacional o de la Nación, como se acostumbra a decir? Generalmente nunca se termina por saber lo que puede haber ocurrido desde que se diseñó el Plan porque, en el camino, se le tiene que cambiar. $Y$ a sabiendas que esto es lo ocurre, surge la planificación estratégica. Y si autores como los citados, acusan diversas interpretaciones y enfoques dentro de una sola organización empresarial concreta, ¿qué puede esperarse para un Estado que pretende planificar a un País entero? Porque no es lo mismo planificar para «aumentar las ventas en conformidad con un enfoque de ventas uniforme», ${ }^{6}$ que planificar el devenir de toda una sociedad. Y si aún para una organización económica es difícil adaptarse a la realidad del mercado ¿qué puede esperarse para la organización de un Estado actuando como planificador e interventor?

Pero el error de origen, el que hace imposible que el Plan de la Nación logre sus propósitos, está en la pretensión gubernamental de pensar la sociedad y diseñar su rumbo. Como señala el Profesor Jesús Huerta de Soto citando a Hayek, la sociedad no es un sistema «racionalmente organizado» por ninguna mente o grupo de mentes humanas, sino que, por el contrario, es un orden espontáneo, es decir, un proceso en constante evolución, resultado de la interacción de millones de seres humanos, pero que no ha sido ni nunca podrá ser diseñado consciente o deliberadamente por ningún hombre. ${ }^{7} \mathrm{Y}$ pretender reunir en un diagnóstico todo ese proceso para elaborar un Plan que rija un número determinado de años para toda una sociedad es una ofensa a esta misma.

desde la visión de los recursos humanos, reuniones para promover la participación; desde las perspectivas políticas, terrenos para ventilar conflictos y redistribuir el poder; y desde la perspectiva simbólica, rituales para señalar responsabilidades, generar símbolos y negociar significados.

${ }^{6}$ Mintzbarg, H., The Structuring of Organizations (1979) Englewood Cliffs, N.J. Prentice-Hall. Pp. 153-154, citado por Bolman y Deal (op. cit., p. 59).

7 Cfr. Huerta de Soto (1994). 
Si, como lo señalan Bolman y Deal, un gerente necesita tomar en cuenta variables que le «ayuden a estimar cuáles son los enfoques que podrían ser más sobresalientes, importantes y eficaces en una situación determinada» y que «entre esos elementos están la motivación, las restricciones técnicas, la incertidumbre, la escasez, el conflicto y la dirección de la operación (hacia arriba o hacia abajo)», 8 ¿qué puede pretender un Estado (sea este capitalista o socialista) con respecto a conocer a toda una sociedad?

Si es el caso de un Estado Capitalista, se hace una Planificación «indicativa», que orienta sin imponer. Si se trata de un Estado Socialista se plantea entonces una Planificación «imperativa» que, por tal, se impone a toda la sociedad, la cual debe obedecer todos los planes y cada quien cumplir las metas planteadas, con lo cual se supone que la incertidumbre desaparece, la escasez no se produce por el Plan sino a causa de los agentes reaccionarios y golpistas y, finalmente, el conflicto desaparecerá al eliminar la división de clases, gracias a la dirección impuesta por Poder Central a todo el conjunto social. Por supuesto que entonces, con unos objetivos impuestos y los recursos asignados desde el centro, la participación no se promueve, sino que se obliga a través del aparato político inmerso en las «organizaciones de base» (consejos comunales, frentes campesinos, obreros, femeninos, juveniles, etc.), los conflictos entre los actores locales y regionales se cortan desde lo alto acusando cualquier desviación de los dictámenes ideológicos, mientras el buró político central distribuye responsabilidades, sacraliza los símbolos y comunica los significados. Obsérvese que, de esta manera, el Estado Socialista se comporta como una organización cerrada y férrea. Pero, como la dinámica social sigue su ritmo natural, se impone, además de la coacción, una creciente represión que va apagando fuegos y hasta eliminando actores económicos, sociales o culturales en un avance del totalitarismo, tal cual ha venido ocurriendo en Venezuela en los últimos doce años.

El totalitarismo, de tal forma, debe ser entendido como un proceso gradual que va surgiendo en la medida en la cual el Estado,

8 Op. cit., p. 339. 
representado en el amo del poder, va descubriendo comportamientos que escapan al control e intervención estatales (sindicatos no oficiales, organizaciones de base no estatuidas, empresas no inscritas en el Plan y sus ramificaciones) y, al mismo tiempo los va penalizando y exterminando por ir contra la naturaleza del Estado.

Este estado de opresión puede sobrevenir, como el caso nuestro en Venezuela, después de un proceso de germinación que ha tenido lugar en el mejor caldo de cultivo para él: el Estado Social. Este proceso fue el relatado en los puntos anteriores y, por su larga duración, conformó una cultura que convirtió al Estado y la Sociedad en cómplices de una degeneración social, política y económica, expresada en la acción estatal benefactora, según la cual casi todas las cosas que se construyeron las hicieron los respectivos gobiernos, nunca la Sociedad o sus actores principales los empresarios.

En conclusión, el socialismo de hoy en Venezuela es el mismo virus del proteccionismo e intervensionismo de ayer, el mismo virus que ha mutado y ahora se presenta con síntomas fatales. ¿Quién y cómo puede inventar una vacuna capaz de detener esta epidemia?

\section{LA OPORTUNIDAD EMPRESARIAL}

Lo primero es tomar conciencia que sufrimos el virus y disponernos a exterminarlo de nuestra existencia. Todos hemos llevado este virus de alguna manera con sólo vivir en este País. Pero resulta que la empresa privada venezolana nunca había estado tanto en la palestra como hoy, más que como villana, tal cual se pretende presentarla, como víctima. Basta con que una parte significativa de la población $(70 \%)^{9}$ rechace las expropiaciones, inscritas dentro de la destrucción del aparato productivo que realiza

9 Estudio sobre expropiaciones en Venezuela, presentado por Datanálisis en el Foro Perspectivas 2011, el 08/12/2010. http:/ / www.analitica.com/va/economia/ opinion/9533126.asp). 
el régimen a través de su política intervencionista y controladora, para percibir lo que puede ser el preámbulo de un nuevo y definitivo despegue de nuestro empresariado, una vez llegue a su fin o estalle en implosión el Estado Socialista que se quiere imponer.

En efecto, en medio de la devastación que va a quedar después de la acción destructiva que se vive en el país, habrá oportunidad para que la población descubra su natural instinto emprendedor, si se logra un ambiente de libertad y respeto a la propiedad privada, a su acción libre en el mercado de bienes y capitales. Pero es necesario comenzar a fertilizar ese terreno de emprendimiento natural, por paradójico que parezca, justo ahora y no sólo después del fin del régimen.

La primera condición necesaria, es que la empresa privada que hoy sobrevive a los ataques y atropellos exterminadores, cambie su visión del espacio social concreto donde se encuentra inmersa, viendo este espacio como un sistema de acciones e interacciones empresariales, induciendo el emprendimiento a través de sus gremios laborales y las organizaciones sociales más proclives al trabajo productivo, es decir, penetrando e invadiendo ese espacio con la lógica capitalista y sus resultados civilizatorios. No hay fórmulas para iniciar este cambio. Cada empresa debe saber leer la dinámica social donde se encuentra inmersa, más allá de sus relaciones productivas con proveedores y clientes, pero utilizando también estas relaciones para fortalecer su liderazgo productivo.

Si la empresa en Venezuela orienta todas sus acciones por el liberalismo económico, para lo cual cuenta con muchos aportes científicos a nivel mundial, estará bien parada en medio de la devastación para emprender acciones endógenas en su espacio social. Esta primera condición ya, de por si, no es tarea fácil dentro de una economía controlada por el Estado, pero el comportamiento liberal empresarial si debe comenzar a inculcarse en la población implicada en el espacio social, así como también debe fortalecerse el tejido productivo y comercial de la zona concernida.

Es absolutamente necesario que las empresas se cuiden sobremanera de no participar en ninguna de las redes de desarrollo endógeno que pululan por todo el mundo «como alternativa al neoliberalismo» y menos aún en la estructura que monta el régimen venezolano actual para levantar su Estado Comunal. 
¿De que se trata entonces cuando planteo el enfoque endógeno como una vía de conexión empresa (s)-comunidad (s)? Primero, se buscaría una conexión activa, en la cual la empresa actúe como modelo de acción emprendedora y asuma su liderazgo natural en el universo productivo. Se trata de mostrar y demostrar que el empresario es una referencia moral aleccionadora en una sociedad corroída por la degradación de valores intrínsecos a la libertad y al desarrollo individual. Es acá donde existe un vacío que el régimen ya no está en capacidad de llenar, ya que es pública y notoria su corruptela, donde sólo le queda acudir a los llamados de solidaridad socialista. Este es de por sí el gran problema del socialismo, que no puede acudir al individuo sin incrustarlo en un colectivo; es por ello que insiste en una formación ideológica que pretende un «hombre nuevo» sin ambiciones ni metas personales hacia una calidad de vida suya. El empresario privado, en cambio, no requiere en lo más mínimo hacer ningún planteamiento teórico liberal, sino inyectar información clara y precisa sobre la manera como él ha levantado su empresa, visto en bienes de capital y no de dinero.

Debe quedar claro acá que esta acción aplica al empresario cierta y comprobadamente honesto, no importa el tamaño de su empresa o empresas, sino su trayectoria pública y privada, la cual debe retratar su búsqueda y aprovechamiento de oportunidades en el mercado de bienes y servicios, aprovechamiento que significó y significa un beneficio para la población venezolana en su calidad de vida.

Si bien este modelaje auténtico es la esencia de la vinculación empresa-comunidad, él debe estar acompañado de unas relaciones laborales justas, donde tampoco debe aparecer el asistencialismo o paternalismo en el cual se cayó durante la larga vigencia del Estado Social. No es mi intención detenerme en este punto, pero si insistir que lo más delicado vienen a ser las relaciones con la comunidad donde se inserta la empresa, ello a partir de una política laboral como la indicada. Y en este campo, como ya lo señalé, no hay fórmulas, sólo que ciencias como la sociología, la antropología y la historia pueden aportar mucho en cuanto a investigar el ethos social y cultural del caso, pero - y esto es muy importante- sin pretender nunca que la información que se 
recabe constituya un dato, a partir del cual se pueden ya tomar decisiones, pues la realidad social, económica y cultural está en constante cambio y no admite fotografías. Y en este aspecto, la visión del empresario es clave, como lo demuestran los logros por él obtenidos en su actividad empresarial. Y esta visión está basada en una información subjetiva, es una información tácita que no se puede plasmar de manera formalizada y objetiva, ni transmitir en cursos, talleres o manuales. La clave acá puede estar en el propio empresario, en la información que él adquiera de la comunidad tanto a través de contactos directos como la que le suministren los científicos sociales, donde a él corresponde hacer la síntesis y orientar el vínculo empresa-comunidad. Y los propios trabajadores pueden intervenir en este vínculo, sin que ello signifique jamás ningún padrinazgo.

La acción empresarial, como acción humana, asume la perspectiva sistémica que le da la dinámica económica donde está inmersa y donde se ajusta día a día en la selva de sistemas de diferente naturaleza. En una sociedad donde se respete la propiedad privada y la acción empresarial, la innata capacidad creativa del ser humano bulle por doquier y se expresa en generación de riqueza, en bienes de capital, en calidad de vida. En una sociedad constreñida como lo está Venezuela hoy, esta capacidad es ahogada por el colectivismo, pero sigue existiendo y se expresa por los "caminos verdes» (término empleado por acá para referirse a los pasos de frontera no legales); es por ello que en estos casos los mercados negros o paralelos proliferan. Pero toda esa dinámica es incontenible y debe ser estimulada y orientada por la empresa privada, sin estruendo, calladamente, como se hace todo acto de liberación.

Como se podrá percibir, en este análisis no entra de manera central lo político ni la política. Y ello es necesario, porque ella atañe esencialmente al poder del Estado y no a la sociedad en sí. Si bien de la sociedad misma emergen los políticos que luchan por el poder, en su mismo afán, ellos llegan a pensar que pueden guiar la sociedad hacia su desarrollo y esto es imposible, pues la sociedad no cabe en ninguna cabeza o doctrina, ella se hace a sí misma en cada momento como crisol de todos los esfuerzos de las personas que la integran y que contribuyen al proceso civilizatorio 
creando nueva información, transmitiéndola y ajustándose unas a otras en sus beneficios y logros. Esta es la única vacuna contra el socialismo y sus progenitores, el proteccionismo y el intervencionismo estatal. Y en Venezuela hay que comenzar a aplicarla ya, sin esperar que el virus avance y destruya cada más el tejido social que tenemos de por sí ya debilitado.

\section{$\mathrm{V}$ \\ ACCIONES A EMPRENDER}

Señalaba anteriormente que la primera condición necesaria, para lograr sembrar un ambiente de libertad y respeto a la propiedad privada, es que la empresa privada venezolana que hoy sobrevive a los ataques y atropellos exterminadores, cambie su visión del espacio social concreto donde se encuentra inmersa, viendo este espacio como un sistema de acciones e interacciones empresariales, induciendo el emprendimiento a través de sus gremios laborales y las organizaciones sociales más proclives al trabajo productivo, es decir, penetrando e invadiendo ese espacio con la lógica capitalista y sus resultados civilizatorios.

Para salirse del juego creado por el viejo Estado Social, pudieran repasarse algunas acciones:

- Formar al personal de confianza de la Empresa en el liberalismo económico y en sus últimos avances científicos y sociales, desmontando las visiones socialistas y/o interventoras que tenemos inculcadas en nuestra socialización. Recordemos que estamos en un país estatista por excelencia, debido a nuestra condición petrolera nacionalizada, negadora de las posibilidades naturales de la acción humana en nuestra sociedad. Si bien ya se ha demostrado que el socialismo es un error intelectual y una imposibilidad, ${ }^{10}$ debemos recordar que el liberalismo científico no predomina en los programas de nuestras

${ }_{10} \mathrm{Al}$ respecto, pueden leerse las obras de Mises, Hayek, etc., o revisar la obra ya citada de Jesús Huerta de Soto, Estudios de Economía Política, 2. a ed. (1994). Unión Editorial, Madrid, en su páginas 29 y 30. 
universidades. Si bien a las empresas les puede resultar costoso y difícil que su personal de confianza logre un acceso directo a la formación liberal, sobre todo en breve tiempo, se debe recordar que «la fuente de todas las voliciones, valoraciones y conocimientos se encuentra en la capacidad creativa del ser humano actor» (Huerta de Soto,1994, p. 29), a partir de lo cual se trata de hacer aflorar esa fuente natural en todos aquellos que intervienen de alguna manera en la dirección de la empresa, en su administración y gerencia. La constitución de un equipo claro en esto es una condición indispensable para poder expandir el pensamiento liberal dentro y fuera de la organización. En esto, asociaciones empresariales y consultores independientes, pueden ser muy útiles para el dictado de talleres intensivos, aplicando el enfoque acá propuesto.

- Está al mismo tiempo la necesidad ya citada de mostrar y demostrar que el empresario es una referencia moral aleccionadora en una sociedad corroída por la degradación de valores intrínsecos a la libertad y al desarrollo individual. Acá se puede requerir el apoyo de personal especializado en elaboración de mensajes que logren inyectar información clara y precisa sobre la manera como el capitán, el timonel, de la empresa ha levantado su empresa, visto en bienes de capital y no en dinero. Al respecto es necesario llenar un vacío de información del cual adolece nuestra población sobre cómo se hacen las cosas - bienes y servicios- que se le ofrecen para su consumo, pues el venezolano sólo tiende a preguntarse cómo acceder a los productos y a su precio, sin valorar en su justa dimensión la cadena productiva y todos los actores que dentro de ella hacen posible ese acceso. Porque no se trata de endiosar al empresario, sino de hacer ver el proceso que éste y sus equipos montaron desde hace años y que mantienen activa su producción minuto a minuto como si se tratara del primer día. La aprehensión de este proceso debe ser todo lo fiel y exacta posible, no en términos de un hecho dado y consagrado, sino de un logro que se tiene que reiterar y mantener en un mercado complejo y difícil, como es todo intercambio humano, donde se trata de valorizar al mercado como oportunidad de acción para cualquiera que se lo proponga. Y esta tarea no es en 
lo absoluto difícil, porque, como ya se ha reiterado, se trata de despejar lo natural del ser humano, eso mismo que, por ejemplo, desarrolla un buhonero (vendedor informal) cuando logra un punto de venta de su producto, punto que, en medio de su informalidad, se incrusta en el anhelado mercado, sólo que se hace de manera marginal y frágil.

- Pero también está la necesidad de plantearse las vinculaciones de la empresa con la comunidad en un clima ajeno al acostumbrado por el Estado Social y, por el contrario, cada vez más cercano al trabajo productivo. No es este un enfoque fácil de expandir, sobre todo en medio de la apología que el régimen mantiene sobre el colectivismo, pero si hay probabilidades de éxito en la medida en la cual este colectivismo fracasa estrepitosamente como creador de riqueza y es acompañado por el fracaso de los servicios públicos del Estado. Se trata de develar la fórmula social del desarrollo sin necesidad de acudir al apoyo, patrocinio o promoción del Estado. Se trata de demostrar que la acción humana emprendedora es lo genuino social.

Las poblaciones locales pueden por si mismas poner en práctica principios liberales en su acción, sin ningún padrinazgo público o privado, por algo muy sencillo, porque la verdadera acción social es solo acción humana interesada en el beneficio de cada uno de sus miembros y con eso basta; es cada uno haciendo lo suyo por lo suyo y los suyos y punto, lo demás es el acuerdo, que es lo social y a lo cual me referiré a continuación.

VI

\section{CRISIS Y OPORTUNIDAD}

La prueba de que el proceso intervencionista venezolano ha degenerado en estos últimos diez años la señala Daniel Morales Romero ${ }^{11}$ : «En la tabla publicada en el link se puede apreciar

11 Morales Romero, Daniel. Revertir el proceso... se puede (2011) Universidad Bastiat. http://universidadbastiat.blogspot.com/2011/01/revertir-el-proceso-sepuede.html 
cómo se ha minado el mercado y la libertad económica en Venezuela desde 1970. El tamaño del Gobierno ha crecido descomunalmente: de una posición de 19 en 1970 pasamos a la 122 en el 2008. En lo que respecta a la infraestructura legal y judicial pasamos del 36 al 135: ¡cuánto retraso! En 1970 el bolívar era la segunda moneda más sana del mundo; en el 2008 la 134. Y éramos el país número 7 más abierto al comercio internacional; hoy somos el 140 (de 141). ¿Y las regulaciones? Teníamos regulaciones más sencillas: en 1970 éramos el país número 26 con regulaciones más promercado en materia laboral, bancaria y de negocios; y ahora somos el 137. ¿Y saben? Me da la impresión, por lo que cuentan, que en esa época la gente progresaba en Venezuela.» Pero no estoy totalmente de acuerdo con esta última afirmación de DMR, pues, a mi entender, el tal progreso estaba asentado en una acción estatal que, si no intervenía directamente constituyendo y administrando empresas básicas, organismos de servicios públicos, líneas aéreas, vías, hoteles, otorgaba créditos blandos a los industriales y manufactureros protegiéndoles con una barrera arancelaria orientada por la nefasta política de sustitución de importaciones, que terminó por convertir los años ochenta en la década perdida en América Latina. El combustible del sistema durante los años setenta y ochenta sería la capacidad financiera y distributiva del Estado, lo cual debilitó a la sociedad para enfrentar tanto la crisis de crecimiento que estalló en 1986 como, posteriormente, en los últimos diez años, la instauración de un Estado Comunal. ${ }^{12}$

Es por esto que, como señala Jesús Huerta de Soto, «las crisis sociales, económicas y políticas que, paradójicamente, son siempre utilizadas por los políticos y «líderes» sociales para justificar ulteriores dosis de intervención (que), en vez de solucionar, crean y agravan aún más los problemas». ${ }^{13} \mathrm{Y}$ es que todos los modelos

12 Tal combustible estatal, sin embargo, inculcó en la sociedad venezolana una idea de progreso y bienestar que hoy hace rememorar a muchos venezolanos aquellos años con la frase «cuando éramos felices y no lo sabíamos», lo que Ramón Piñango y Moisés Naím trataron en su libro El Caso Venezuela: Una Ilusión de Armonía (1985). Caracas, Editorial: Ediciones IESA.

${ }^{13}$ Huerta de Soto (2007), p. 22. 
de desarrollo que aceptan la existencia de un Estado (aunque sea mínimo) entendido como la agencia monopolista de la coacción institucional, llevan en su interior el germen del fracaso social en $\mathrm{su}$ «intento de organizar cualquier parcela de la vida en sociedad mediante los mandatos coactivos de intervención, regulación y control procedentes del órgano monopolista de la agresión institucional (Estado)». ${ }^{14}$

A mi entender, es necesario comenzar a construir espacios sociales con incrementos de márgenes de libertad en los espacios sociales concretos donde actúan las empresas venezolanas dentro del territorio nacional. Y tales incrementos tiene que ser producidos desde las empresas, no hay otra posibilidad visible en estos momentos. La propia crisis económica, social y política que el régimen actual en Venezuela ha creado, permite introducirse en los sistemas sociales concretos, utilizando lo que la cibernética recomienda en casos de situaciones entrópicas donde predomine el caos, que es lo que ocurre hoy en nuestro país. Al respecto, la Teoría de los Sistema aconseja aplicar inyecciones de información, justo lo que venido recomendando en el punto anterior en las acciones de (a) formación de personal de confianza, (b) valoración de la referencia moral aleccionadora del empresario y (c) creación de un clima social cada vez más ajeno al Estado Social y más cercano al trabajo productivo.

Todo nos sigue indicando como es posible aprovechar el caos burocrático del Estado para realizar acciones privadas que sólo acudan a los servicios públicos en lo mínimo necesario. Cuando la comunidad se encuentra a si misma para llevar adelante un acción concreta que le interesa, acopiando y administrando recursos diseñando el proceso, supervisando las obras y haciendo el seguimiento y obtiene un resultado satisfactorio, se demuestra en los hechos que el Estado Social y, más aún, el Estado Comunal, en lugar de beneficiar a la población, obstaculizan su crecimiento y desarrollo.

En términos comunales, es cada uno haciendo lo suyo por lo suyo y los suyos y punto, lo demás es el acuerdo, que es lo social.

14 Op.cit., p. 19. 
Y es en este acuerdo donde la empresa de cada caso (la implicada socialmente) puede y debe intervenir, no costeando directamente la acción, pero si apoyándola con algún recurso material o humano. Pero la empresa debe, además, tratar de proteger la naturaleza liberal de ese acuerdo, o sea, que no sea penetrado por el virus del socialismo, lo que puede ocurrir si alguno de los integrantes de la vecindad o comunidad, propone buscar un apoyo estatal. Si bien es obvio que, dada la estructura y dinámica impuesta por el Estado Social y su derivado Comunal, al final de cuentas habrá que acudir a un organismo público en busca de un servicio, lo importante es presentarse con el trabajo previo ya hecho y decirle al representante o encargado del servicio del caso: lo que queremos es que ustedes ahora pongan o suministren el servicio en el sistema que hemos montado nosotros a nuestro coste y esfuerzo, donde lo importante a tomar en cuenta es el valor social del proceso, más que el logro del mismo.

VII

\section{LA ACCIÓN PRIVADA EN LO SOCIAL}

Cuando señalo que lo importante a tomar en cuenta en toda acción privada vecinal o comunal es el valor social del proceso, más que el logro del mismo, el valor central que acá funciona es el de la propiedad.

El espacio comunal, según lo dictan las actuales leyes venezolanas, debe ser gestionado por la comunidad. Lo difícil es determinar quien piensa a la comunidad como un todo. Pero debe evitarse el enfoque estatista en lo comunal, el cual pretende que los consejos comunales representan el poder comunal, el cual a su vez depende del gobierno federal central, ya que éste le impone los criterios para elaborar proyectos admisibles y otorgarles recursos financieros. Y para evitar este manejo debe propugnarse la acción privada a través de asociaciones de vecinos, condominios o cualquier otra figura donde puedan agruparse los vecinos de cada caso para resolver un problema o una carencia que los afecte a todos y cada uno; pero esta resolución debe ser con recursos y esfuerzos propios. Cualquiera que sea el problema 
resolver, siempre habrá que tomar decisiones sobre el cómo, con qué y con quién. El cómo tiene que ver con el diseño de la acción a ejecutar, la cual debe ser pensada y decidida por los vecinos mismos. El con qué se constituye en el aporte de cada uno. Los bienes que se adquieran para ejecutar la acción (materiales, equipos, etc.) quedarán como activos de la vecindad y lo importante es que sus integrantes tomen conciencia de esto, pues ellos actuaron como propietarios para otorgarle un nuevo valor a lo que es de ellos, porque lo crearon y lo utilizarán en su beneficio haciendo del espacio su espacio, ampliando así su sentido de propiedad.

Este razonamiento tan sencillo es difícil de concebir en nuestro país por los decenios que tiene el enfoque estatista. Si bien en las principales ciudades los sectores de clase media han comenzado a desarrollarlo, en las zonas suburbanas y barriadas sigue predominando la actitud de demandar del Estado todo lo referente a las necesidades del espacio vecinal. Aún las clases medias bajas participan de esta dependencia estatal, llegándose al extremo en general de considerarse normal el no pagar servicios públicos como la electricidad y el agua, utilizando como motivación su baja calidad. El punto central es que la acción social es acción humana. Que cuando hacemos algo por resolver una situación del hábitat, lo hacemos por nuestro beneficio personal y el de nuestra familia; y que cuando nos unimos con nuestros vecinos para lograr mejorar ese hábitat todos estamos interesados en lo mismo, en mejorar lo que es nuestro, nuestro edificio, urbanización, sector o barrio.

Toda esta consideración sobre la acción social a nivel del hábitat, la he realizado haciendo abstracción de la presencia de una empresa en ese espacio social, con el simple propósito de hacer ver que la esencia de lo social no es lo colectivo sino la acción humana concretada en personas que convergen en sus intereses personales con respecto a un asunto por resolver porque atañe a sus condiciones de vida, sin necesidad de que emerja o se inculque ningún sentimiento colectivo. Y es que, contrario a lo que se pretende desde el socialismo, la comunidad no es un actor colectivo sino un espacio de convivencia más o menos permanente (depende de su condición urbana, suburbana o rural) y, como tal, contiene intereses particulares (viviendas, comercios, talleres, etc.). 
Y el espacio residencial, comunal o vecinal que comparten día a día es del interés de cada uno en la medida en la cual requiere ser intervenido para su mantenimiento, adecuación y desarrollo.

Debe quedar claro también que la vinculación de cada quien con su espacio residencial depende de múltiples e innumerables factores y motivaciones imposibles de uniformar o tratar como un todo homogéneo. Si en algún momento hay una unidad de criterio para una acción social, esta unidad siempre es circunstancial y tiende a desaparecer una vez que se logra el objetivo propuesto, por ello es muy importante que el mayor número posible de ellos, los que participaron de alguna manera en el proceso o acción, tome conciencia de lo que ocurrió y lo valore como lo que es, una acción privada que hace a cada uno más propietario aún de su vivienda o espacio de acción y que, por ello mismo, no es una acción colectiva, sino el encuentro y acuerdo de varios por una circunstancia determinada, circunstancia que, una vez resuelta, valora aún más la propiedad de cada uno beneficiándolo en su patrimonio.

¿Qué es lo que puede unir a unos habitantes más allá de los servicios y circunstancias públicas comunes de su hábitat? Algo de suma importancia, lo que crean cada día con su trabajo e iniciativa, lo que producen e intercambian, la manera como logran satisfacer sus múltiples necesidades dentro de su propio espacio social, en una palabra, el mercado. Y acá entramos en el fundamento básico de la sociedad, lo que hace que ella se reproduzca como tal y produzca nueva sociedad constituyendo el progreso infinito de la acción humana: la civilización.

\section{VIII}

\section{DESBROZANDO EL TERRENO SOCIAL}

Me siento inclinado a reflexionar a partir de lo que Habermas señala en sus Ensayos Políticos como La crisis del Estado de bienestar y el agotamiento de las energías utópicas. ${ }^{15}$ Sin cuadrarme con

15 Habermas (1988), pp. 113-134. 
este autor, quiero simplemente tomar como referencias algunos de sus señalamientos con respecto al Estado Social y las utopías, ya que al partir del Estado Social impuesto en Venezuela mis reflexiones sobre la gestión de un espacio social proclive a la iniciativa privada corren el riesgo de caer en el terreno utópico, algo que no quisiera y que trataré de evitar. Habermas nos dice en sus Ensayos: El pensamiento político impregnado de la actualidad del espiritu de la época y que trata de resistir la presión de un presente cargado de problemas, está penetrado de energías utópicas; pero, al mismo tiempo, es conveniente que este exceso de esperanzas se someta al contrapeso conservador de las experiencias históricas. ${ }^{16}$ En estas reflexiones justamente he evadido el pensamiento político imperante y si de experiencias históricas se trata, a nivel concreto, existen acciones empresariales en Venezuela que, en algunos casos han tenido resultados apreciables como desarrollos comunitarios, así como otras han caído en el mismo vicio del intervencionismo, en este caso un intervencionismo empresarial. Pero el hecho es que en Venezuela ha habido y hay experiencias concretas de lo que he señalado. Ahora, si se me pregunta de alguna sociedad que haya ensayado este enfoque, respondo que no hasta donde llega la información histórica con la que cuento, aunque si hay también experiencias semejantes en otros países, incluyendo América Latina.

De todas maneras, mi pretensión no va más allá de sugerir un tipo de acción que permita ir desbrozando el terreno social desde una perspectiva liberal capitalista que le brinde en concreto climas propicios a la empresa privada para encontrar su propio liderazgo. Como dije al inicio, el fracaso de la actual acción estatal puede ser una coyuntura favorable, a condición de que se actúe con suma prudencia y sin confrontación con el Estado y sus tentáculos.

Según Habermas, ...Después de la Segunda Guerra Mundial todos los partidos gobernantes en los países occidentales ganaron sus mayorías al actuar a favor de los objetivos del Estado Social y desde fines de los años setenta están haciéndose evidentes los límites del proyecto del Estado social sin que, hasta la fecha, sea visible una forma

16 Op. cit., p. 114. 
sustitutoria nitida.... el programa del Estado Social siguiendo la utopía de la sociedad del trabajo, ha perdido la capacidad de formular posibilidades futuras de alcanzar una vida colectiva mejor y más segura. ${ }^{17} \mathrm{Y}$ acá yo pregunto, ¿por qué tenemos que seguir orientándonos por estados o situaciones de vida colectiva?, ¿por qué no tomar a la acción humana individual en su tendencia natural al beneficio y estudiarla y trabajarla en los espacios sociales donde actúan las empresas privadas justo en un país con una imposición tan colectivista como lo es el nuestro? ¿Se es utópico al buscar esto?

Si el Estado Social democráticamente legitimado para regular el proceso de crecimiento natural capitalista en Venezuela derivó hace doce años en la imposición paulatina de un Estado Comunal que busca detener el crecimiento capitalista e irlo suplantando por una economía primitiva impregnada de colectivismo y, además, no se ven salidas políticas inmediatas a esta imposición, aunque todas las mediciones de opinión favorecen la iniciativa privada, ¿no es entonces válido plantearse acciones de sobrevivencia social concreta que sirvan, además, de rescate a una población desencantada del debate político?

Habermas, sin embargo, nos coloca en una disyuntiva absurda cuando nos señala por una parte: Aquellos países que aún están atrasados en el desarrollo del Estado social no tienen razón alguna para separarse de este camino, y luego teme que: ...el capitalismo desarrollado no pueda vivir sin el Estado social y, al mismo tiempo, tampoco pueda hacerlo con él. ${ }^{18}$ ¿Qué queda entonces, por ejemplo, para nosotros en la Venezuela actual? Indudablemente, nuestro país había logrado avanzar algo en el desarrollo del Estado Social, pero nunca tuvimos un capitalismo desarrollado y si sufrimos ahora, en cambio, una destrucción implacable de nuestro aparato productivo privado. Y mi planteo es que la permanencia del Estado Social sin un desarrollo capitalista real y contundente nos llevó a la trampa del actual Estado Comunal, del cual tampoco se trata de salir para caer de nuevo donde estábamos, en la beneficencia social, por más atractivo que resulte para muchos. Y muy

17 Op. cit., p. 117.
18 Op. cit., p. 120. 
lamentablemente, la inmensa mayoría sino todas las posturas políticas opuestas al régimen nos quieren llevar de nuevo al viejo y fatal camino que traíamos, mientras, paradójicamente, la medición de las expectativas sociales muestra a éstas favorables en buena medida al desarrollo capitalista, donde no creo que sea utópico pensar en la posibilidad de ir creando, preservando o fortaleciendo espacios de emprendimiento capitalista. Y no comparto la pretensión de los legitimistas, si como lo señala Habermas, en su condición de auténticos conservadores,... esperan encontrar el punto de equilibrio entre el desarrollo del Estado social y la modernización por medio del mercado. ${ }^{19}$ Si para algo ha servido la fatal experiencia que hoy vivimos en Venezuela es justamente para demostrarnos hasta la saciedad que el Estado Social no permite la modernización por medio del mercado y si la obstaculiza y somete a riesgos como este que vivimos acá.

Obsérvese por otra parte que no he me centrado en la variable laboral, a pesar de hablarle a la empresa privada. Y es que, como señala el mismo Habermas, se ha agotado ya el potencial innovador de la utopía de la sociedad del trabajo. ${ }^{20} \mathrm{Y}$ es que si el movimiento obrero dejó de ser el proyecto de movimiento social que tuvo hace siglo y medio, ni el cooperativismo, ni la autogestión, ni la cogestión constituyen tampoco una vía que lleve a algún sitio prometedor. Y no se trata tampoco de sustituir la utopía de la sociedad del trabajo por otra especie de utopía de la sociedad del mercado. Si bien busco reivindicar a éste en los espacios sociales concretos, esto pasa por la reivindicación del individuo y sus circunstancias, tomando el rescate de una de las que tiene mas amenazada como circunstancia vital, la de su hábitat, valorizando la acción privada en ella. Y, en este sentido, si considero con Habermas que es necesario que se fortalezca la autonomía de un mundo vital que está amenazado en sus fundamentos vitales y en su estructura interna comunicativa. ${ }^{21} \mathrm{Y}$ cuando hablo del individuo me refiero a su aspecto productivo, pero también, al del consumidor, al ciudadano y al cliente de las burocracias del Estado de

\footnotetext{
19 Op. cit., p. 121.

20 Cfr. op. cit., p. 124.

21 Op. cit., p. 123.
} 
bienestar. ${ }^{22} \mathrm{Y}$ con respecto a este último rol, planteo la necesidad de limitarlo lo más posible y hasta doblegar estas burocracias con el avance de la innovación privada.

Si creo con Habermas que el Estado social, en su desarrollo, ha entrado en un callejón sin salida. En él se agotan las energías de la utopía de la sociedad del trabajo, pero tampoco deben ser sustituidas por el atractivo único de otra energía, la del libre mercado, es necesario asumir también los espacios sociales. En este aspecto también creo cierto aquello de que la capacidad de acción de organizaciones cercanas a la base irá siempre por detrás de su capacidad de reflexión (HJ), por ello planteo levantar para cada caso local un trabajo de acompañamiento y apoyo a la acción social privada para que no se deje apropiar su hábitat y busque desarrollar todas sus potencialidades, entre las que está por fundamento el mercado como encuentro de la acción humana en su innovación, intercambios y ajustes continuos.

IX

\section{LA REALIDAD SOCIAL Y EL TOTALITARISMO}

Si la realidad social es compleja, dinámica y cambiante, en el caso de la Venezuela de hoy estas características se agudizan hasta alcanzar un nivel crítico sin precedentes. Señalo esto porque en ningún momento se debe obviar o pasar por alto o a un plano secundario, la agresión que se está produciendo a los cimientos de la sociedad. Si bien el régimen político que se ha impuesto acá admite todos los epítetos negativos imaginables, hay que definirlo en su propia esencia, más allá de los calificativos que le dan sus propios autores y los que les asignan los opositores. Ya no se trata de discernir si vivimos una democracia o una dictadura, pues algo más profundo se está tratando de imponer. Un concepto básico funciona detrás del juego político: Totalitarismo. Para examinar lo que nos ocurre tomaré un autor. Claude Lefort. ${ }^{23}$ Seleccionaré fragmentos claves de él para ir reflexionando nues-

22 Cfr. op. cit., p. 123.
23 Lefort (1983). 
tro caso venezolano.

Después de haber apoyado la Revolución en la URSS y haber pasado a militar inmediatamente en el partido trotskista, Lefort percibe cómo el totalitarismo desvirtúa la naturaleza de la sociedad donde se impone: En el fundamento del totalitarismo se localiza la representación del pueblo-Uno. Comprendamos que se niega que la división sea constitutiva de la sociedad. En el mundo llamado socialista sólo podría haber división entre el pueblo y sus enemigos: una división entre el interior y el exterior y no una división interna. Después de la revolución, el socialismo no sólo es considerado como llamado a preparar el advenimiento de una sociedad sin clases: debe ya hacer manifiesta esta sociedad que contiene el principio de una homogeneidad y de una transparencia en sí. ${ }^{24}$ Se comprende así que el actual régimen venezolano no concibe a la sociedad como compuesta por dos categorías, llámense estos chavistas y no chavistas, gobierneros y opositores, o lo que sea. Ellos - los del régimense definen como el pueblo, la verdadera sociedad que buscan imponer y el resto son sus enemigos y en esto no cuentan las cantidades o porcentajes de población que vota, opina, apoya o reclama. Es el pueblo-Uno que contiene el principio de la homogeneidad dentro de la cual no son posibles ni aceptables ni imaginables divisiones. La única división que por ello se acepta como existente es la que se afirma entre el pueblo-Uno y el otro. Y este Otro es el otro del afuera. Expresión que hay que tomar al pie de la letra: el Otro es el representante de las fuerzas procedentes de la antigua sociedad (kulaks, burguesía) - para nuestro caso venezolano lo que llaman la IV República- y es el emisario del extranjero, del mundo imperialista. Esta concepción tiene una gran utilidad práctica para ellos, pues la constitución del pueblo-Uno exige la producción incesante de enemigos. No sólo es necesario convertir fantásticamente adversarios reales del régimen y opositores reales en figuras del otro maléfico; hay que inventarlas. ${ }^{25}$ Es por ello que desde el que funge de Presidente hasta el funcionario más oscuro, pasando por cualquier juez, califican a cualquier poblador que

\footnotetext{
24 Op. cit., p. 16.

25 Ídem.
} 
no se identifique con el pueblo-Uno como enemigo, no importa si lo que haya dicho o hecho o simplemente pensado sea insignificante y no tenga consecuencias reales, es el otro, pero no del mismo patio en tiempo y espacio, ya que es el pasado $y$, aunque hoy esté físicamente en el territorio del pueblo-Uno, es emisario del extranjero, no importa que no existan pruebas de ello, ya que, al no identificarse con el pueblo-Uno, ya no es. Y para ellos es importante que exista, porque el Uno requiere al otro mientras se logra el objetivo: el advenimiento de una sociedad sin clases.

Las campañas de exclusión, de persecución, ponen de manifiesto una imagen nueva del cuerpo social. El enemigo del pueblo es considerado como un parásito o residuo que hay que eliminar. Y esta es otra clave del totalitarismo, el exterminio. El nuevo cuerpo social que se quiere formar repele al otro hasta la negación, según lo cual, no debe existir o simplemente coexistir con el pueblo-Uno, tiene que desaparecer. ${ }^{26}$ Por exagerado, enfermizo e increíble que parezca, esta es la búsqueda esencial, lo demás -democracia, elecciones, leyes, parlamento, judicatura- es adorno momentáneo que, a la larga ha de desaparecer.

La persecución de los enemigos del pueblo se ejerce en nombre de un ideal de profilaxis social, ${ }^{27}$ en el sentido de velar en defensa de, velar sobre, velar por, tomar precauciones contra, estar en guardia. Por ello el portavoz del pueblo-Uno, el dirigente máximo, tiene que demostrar que está permanentemente en guardia y debe hacer presencia e imagen constante como el gran vigilante, de allí la omnipresencia del que funge de Presidente por todos los medios posibles en largas apariciones donde da fe de la profilaxis social.

Todo ocurre como si el cuerpo sociopolitico del régimen debiese asegurarse de su propia identidad, expulsando sus residuos o bien como si debiese cerrarse sobre si mismo sustrayéndose al exterior, conjurando la amenaza de una fractura que hace pesar sobre él la intrusión de elementos extranjeros. ${ }^{28} \mathrm{Y}$ es por ello que las supuestas divisiones

$\begin{array}{ll}26 & \text { Ídem. } \\ 27 & \text { Ídem. } \\ 28 & \text { Ídem. }\end{array}$ 
que haya tenido políticamente en su interior el régimen no tienen porque afectarle, por el contrario, le permiten cerrarse sobre sí mismo e identificar hasta la disidencia más íntima como intrusión extranjera. Y extranjero no es lo extranacional, sino todo lo que no es el pueblo-Uno. Por ello es importante que existan y aparezcan purificaciones, de las cuales nadie está exento, salvo quien personifica al pueblo-Uno.

La campaña contra el enemigo es afiebrada; la fiebre es buena; es la señal, en la sociedad, del mal que hay que combatir. ${ }^{29}$ Esto va creando un clima de terror que invade a todo el que no es el puebloUno. Cualquier medida administrativa se lleva a cabo con acompañamiento militar, el líder máximo, el único, el que encarna al pueblo-Uno, alienta con su verbo encendido - afiebrado- invasiones de terrenos, viviendas y empresas privadas, no importa si esto produce atropellos, injusticias y parálisis productivas, lo importante es que la fiebre del socialismo se sienta y persista como una señal del mal que hay que combatir, señal que el líder único identifica como privilegios de la burguesía; y, al señalarlos e identificarlos con nombre y apellido (empresarios, estaciones de radio y televisión, periódicos) logra que el pueblo-Uno vea a sus enemigos claramente y vaya contra ellos como los residuos de la antigua sociedad que hay que expulsar o exterminar.

Se descubre aquí todo un encadenamiento de representaciones, cuya lógica no podría escapársenos: identificación del pueblo con el proletariado, del proletariado con el partido, del partido con la dirección, de la dirección con el Egócrata. ${ }^{30}$ Esta característica del totalitarismo también se cumple y se ha venido cumpliendo en Venezuela, donde funciona el PSUV (Partido Socialista Unido de Venezuela) como correa de transmisión de las directrices que emanan de los jefes políticos, los cuales llegan a cambiar según los designios de Egócrata, como lo califica Lefort tomando el término de Solyenitzin. Este proceso de identificación mantiene la obediencia al líder máximo por lo que él encarna, el proceso infinito de la revolución, 
ya que los niveles de representación se transparentan en él, haciéndolo infalible ante el pueblo-Uno.

Se produce una especie de positivización de la ley, evidente en la intensa actividad legislativa, jurídica, al servicio del Estado totalitario. ${ }^{31}$ Esta característica es muy notable en Venezuela, pues de manera flagrante se toman decisiones judiciales que van contra la Constitución Nacional (la misma redactada por ellos en 1999) con el objetivo de profilaxis social ya mencionado y su consecuente persecución de aquellos que no se identifican con el pueblo-Uno, lo cual es apoyado por una febril actividad jurídica en la Asamblea Nacional para atender de manera expedita los deseos y designios del Egócrata, a lo cual se añade el apoyo de la Fiscalía para así colocar todo el entramado legal al servicio del ansiado Estado Totalitario.

La perversión de la función del poder, de la ley, del conocimiento, no lo ocultemos, produce efectos sobre el conjunto de la vida social, mientras que no hay o ya no hay adhesión al régimen. ${ }^{32}$ Este señalamiento de Lefort advierte algo terrible a tomar en cuenta, como es el hecho que el porcentaje de adhesiones al régimen no tiene ya efectos sobre la perversión del poder y su funcionamiento, lo cual nos indica el poco o relativo valor que tiene la pérdida de popularidad o apoyo al proceso totalitario ya iniciado.

El Egócrata... ofrece, él mismo, su cuerpo individual, mortal, ataviado con todas las virtudes, cuando se llama Stalin o Mao o Fidel -o Chávez para nuestro caso-. Se trata de un cuerpo mortal que es percibido como invulnerable, que condensa en él todas las fuerzas, todos los talentos, desafía las leyes de la naturaleza por su energía de supermacho. ${ }^{33} \mathrm{Y}$ esta imagen que nos refiere al título del escrito de Lefort (La Imagen del Cuerpo y el Totalitarismo) es muy explicativa de la percepción que trata y logra el Egócrata desarrollar en los ganados para el pueblo-Uno, percepción que, ciertamente, va más allá del cuerpo mortal, lo cual nos advierte acerca las raíces casi mágicas que va tomando el fenómeno personificado.

\footnotetext{
31 Op. cit., pp. 16-17.

32 Ídem.

33 Ídem.
} 
La nueva sociedad se presenta como una organización única que abarca una red de micro-organizaciones,...donde lo social se define como organización y como lo organizable. ${ }^{34} Y$ esta característica es muy importante a recordar para el propósito de estas notas, pues ella atañe justo a lo social local y su dinámica, como examinaré posteriormente.

Con respecto a la democracia, el totalitarismo,... al mismo tiempo que la derroca, se apropia de algunos de sus rasgos y les da una prolongación fantástica. ${ }^{35}$ En esto el régimen ha manejado el sistema electoral a su antojo, llegando a obtener reconocimiento internacional y prolongando los actos electorales hasta lograr crear una ilusión de salida electoral a la oposición política.

\section{$X$ RENOVANDO ESPACIOS HUMANOS}

En realidad podría subtitular «Renovando Espacios Sociales», pero opto por lo humano para destacar que se trata de rescatar la naturaleza humana cotidiana del individuo en sociedad: la innovación, el intercambio, el beneficio y el reajuste dinámico en las relaciones sociales. Por supuesto que tales son las características que dicta el liberalismo con respecto al mercado, pero propongo algo más en ello. Hay grados de arraigo y pertenencia, hay hábitos, compartidos o no, que pueden favorecer o obstaculizar el desarrollo normal de las relaciones, hay creencias y valores ancestrales, hay grados diferentes de conocimiento e información sobre las cosas que intervienen en sus vidas; todo esto y mucho más constituye lo social, entretejiéndose con lo económico y lo cultural según se trate de espacios rurales, urbanos o suburbanos. Pero también hay algo que interviene y condiciona esos espacios, sobre todo en nuestra sociedad, el Estado, un Estado que, cómo hemos visto, ha sido siempre interventor y que hoy, de manera perversa, busca ser cada vez más controlador de la vida social.

\footnotetext{
34 Ídem.

35 Op. cit., p. 18.
} 
La paradoja de un régimen totalitario es que, conforme controla más, surgen salidas sociales que escapan a su imposición. Podría decirse que cada control crea su mercado paralelo, donde la sociedad actúa y logra lo que requiere, a un precio muy alto, pero lo logra. Y es esto lo que hace cada vez más represivo al régimen en su empeño de conducir a la sociedad hacia un destino que nadie ve en los hechos, pero que funciona como plan, programa, doctrina, en la propagación ideológica incesante del alto mando totalitario.

Examinando el caso venezolano, la paradoja citada adopta múltiples formas. Así por ejemplo, el control cambiario, crea el mercado paralelo, mercado donde también actúan funcionarios y dirigentes del régimen, por aquello de la tendencia humana al beneficio. El control de precios en los alimentos con importación subsidiada (PDVAL, Productora y Distribuidora Venezolana de Alimentos S. A.) nutre el mercado de los vendedores ambulantes (buhoneros), quienes actúan a la manera de unos corredores de bolsa de valores, comprando productos que van a escasear para venderlos en el momento justo. Más aún, en la medida en la cual el régimen cierra, expropia y arruina empresas y comercios, surgen empresas y comercios informales que buscan y logran escapar a las sustracciones del SENIAT (Servicio Nacional Integrado de Administración Aduanera y Tributaria) y a la creciente permisología burocrática estatal, la cual siempre viene acompañada de la extorsión y el chantaje de quienes fiscalizan, incluyendo los órganos de seguridad, más aún si se toma en cuenta que un régimen totalitario cuenta siempre con apoyo y fuerza militar.

$\mathrm{Y}$ el fondo en todo esto es que el régimen se alimenta de su enemigo y ellos todos lo saben y aprovechan. Los funcionarios de cada nivel logran buenos ingresos conforme ascienden en la escala, pues no es lo mismo cobrar por un permiso sanitario a una venta de comida, que exigir una comisión por sobreprecio a una importación de alimentos o insumos industriales. Si uno se pasea mentalmente -en el caso venezolano- por todas las posibilidades que otorga el régimen de control estatal en toda la complejidad productiva y distributiva (desde las industrias básicas hasta el comercio más pequeño), entenderá porque y cómo mantiene sus lealtades. Entiéndase bien que se trata de un enriquecimiento 
sin trabajar, con lo cual se cumple el axioma liberal que el beneficio económico individual es una búsqueda humana indetenible.

Pero no se trata acá de ver por qué y de qué se mantiene el régimen, sino de cómo crear espacios sociales naturales ajenos a él y a sus intenciones antisociales. Y resulta que esos espacios los crea el propio régimen, tal acabo de ejemplificar muy brevemente. Es por ello que propongo cambiar el centro del análisis de la situación venezolana. No se trata sólo de combatir al régimen políticamente, sino de ganarle terreno en el plano social, productivo y cultural. Esta es mi propuesta central.

Conforme el régimen ha ganado terreno en su totalitarismo, se observa que en los sectores de clase media han ido surgiendo pequeñas y hasta medianas empresas informales que logran así evadir el control, la extorsión y la permisología estatal, intercambiando sus productos con negocios afines y hasta formales. Mientras los sectores bajos se dedican mayoritariamente a la buhonería, los sectores medios son más propensos al negocio o empresa familiar como una manera de palear la situación de ahogo impuesta por el régimen a la iniciativa privada. En ciertas áreas, como la de restaurantes y hospedajes, ventas de artesanía, pequeñas galerías de arte, agencias de festejos, etc., surgen propuestas ya formales, a sabiendas que los tentáculos del régimen no los alcanzan, pues al totalitarismo le interesa apropiarse antes que nada de lo que conforma la cesta básica y las empresas primarias tildadas de estratégicas, como las extractivas y metalúrgicas, además de las cadenas comerciales más emblemáticas del capital criollo. Pero el ingenio humano sigue indetenible creando flujos de mercado libre entre los islotes de las empresas públicas cada vez más improductivas debido a la falta de estímulo que da el beneficio y a la ausencia de capacidad empresarial.

Es así como en barrios, pueblos y urbanizaciones se van creando espacios productivos que, si bien no representan algo significativo para el aparato productivo, mantienen vivo el germen del emprendimiento privado, constituyendo pequeños espacios que es necesario tomar muy en cuenta para mi propuesta de renovar los espacios sociales. O sea, que los veo como puntos de referencia para estimular el espíritu emprendedor. Debo aclarar que no se trata en ningún momento de alentar la constitución de 
cooperativas o microempresas promovidas por el Estado. Y en esto no hay motivo de preocupación, pues el Estado interventor coloca su impronta improductiva socialista en cualquier programa que establezca, promueva o financie, como, por ejemplo, exigir la inclusión de empleados en cooperativas familiares, pretender una horizontalidad en la gestión, tratar de imponer cadenas de distribución, etc. Y la población que quiere emprender su propia empresa sabe que en tales espacios perderá su libertad y se le pondrá un techo a sus beneficios, motivo por el cual esos programas se convierten en fósiles inmediatamente.

¿Cómo aprovechar tales microempresas para renovar los espacios sociales? Es acá donde se requiere la presencia y disposición de empresas privadas ya constituidas, pero no sólo las grandes o medianas empresas, sino también los pequeños comercios y centros de servicios electromecánicos, latonerías, cybers, restaurantes, hosterías. Se trata de entretejer y compartir una red de liderazgo empresarial con sentido local y zonal, es decir, que responda a los intereses del arraigo de la población concernida. Y en esto pueden jugar un papel importante las asociaciones gremiales de comerciantes, ganaderos, agricultores y profesionales constituidas a niveles locales donde tengan en común compartir con la misma población sus problemas más importantes, sus posibilidades y anhelos. Estos encuentros tienen que ser promovidos por alguna (s) de las empresas, cuidando que no se convierta en un tutelaje.

Se sugiere tomar como modelo a los grupos de pertenencia y referencia. Si los primeros son aquellos a los cuales el individuo se halla integrado de manera plena, los de referencia, tal como su nombre indica, son tangenciales en las actividades cotidianas del individuo. Hay que tener cuidado al aplicar esta clasificación, ya que, por ejemplo, si la familia nuclear (padres e hijos) constituye un grupo de pertenencia casi por concepto, pueden darse casos en los cuales no es así, bien sea por desarraigo familiar, abandono, etc., mientras que un equipo deportivo puede constituir para alguien un grupo de pertenencia por la manera en la cual está identificado con él, el valor central que le otorga a esa práctica deportiva. Un partido político puede ser un grupo de pertenencia para un dirigente fundador, mientras sólo es, quizás, de 
referencia para un simpatizante o colaborador. De tal manera, en una comunidad determinada ciertos grupos pueden tener gran atracción entre los pobladores, al grado de considerarlos muchos como un grupo de pertenencia, mientras que otros son para la mayoría de referencia. Hay personas que están muy integradas a su trabajo y muestran una situación de pertenencia a su equipo laboral u organización, mientras otros la tienen hacia un club o una iglesia. Dependiendo del grado de identificación, inmersión en la estructura del grupo, en sus normas y valores, objetivos e intereses, así como de la permanencia en la relación e interacción en una comunidad, es posible ubicar a cada persona según sus relaciones de pertenencia y referencia.

Lo primero que hay que analizar para el caso que nos ocupa es el grado de pertenencia que tienen los gremios de productores y comerciantes de la localidad de que se trate. Hoy en día en Venezuela esto es muy importante, ya que, debido al ataque frontal y constante que el régimen totalitario ha venido ejecutando contra los empresarios privados durante años, en unos casos estos gremios han cerrado filas para protegerse y defenderse, en otros se ha producido una especie de diáspora producto de las expropiaciones, cierres, confiscaciones y persecuciones recibidas por el sector. En cualquiera de los dos casos, se hace necesario revisar la situación y comenzar a reconstruir los grupos de acuerdo a la perspectiva acá propuesta de liderazgo creciente en un clima de emprendimiento privado con innovación, intercambios y reajustes propicios a la acción liberal capitalista. A continuación ahondaré en este aspecto.

\section{$\mathrm{XI}$ RENOVANDO GREMIOS EN PLENA CRISIS}

Para abordar el tema de los gremios productivos y su reproducción es necesario tomar perspectiva en la situación crítica en que se encuentra el país, lo cual, por doble partida, afecta a estos gremios, ya que, además de sufrir la crisis como resultado de la política cambiaria, de los controles de precios, de la extorsión a través de la permisología, han sido y son objeto de persecuciones, 
amenazas, intervenciones arbitrarias y expropiaciones a sus bienes y activos.

Como he venido señalando, el actual régimen busca imponer un Estado Comunal, para alcanzar el cual es necesario instaurar un Estado Totalitario. En esta tarea se ha dedicado a reducir el espacio del sistema anterior (Estado Social con inspiración capitalista) con la meta de hacerlo desaparecer e imponer su pretendido sistema socialista.

De tal manera, en busca de su propósito, el régimen ha redimensionado la crisis misma que le llevó al poder, pretendiendo manejarla hasta lograr imponer su sistema. Esto hay que verlo con detenimiento, pues nadie es dueño de una crisis. El concepto de crisis es amplio y complejo en sus ángulos. Trataré de ilustrar algunos.

Alfred Pockran, en su estudio de las crisis, ${ }^{36}$ ha dejado sentadas varias tesis interesantes. Primero observa que toda crisis tiene sus comienzos mucho antes de que estalle realmente. Así, por ejemplo, Einstein publicó sus teorías de la relatividad en el período 1905-1915, cuarenta años antes de que su labor culminase en el final de una guerra, el comienzo de una edad nueva y el primer estallido de una crisis.

Hay «otro factor» que convierte la crisis en completamente intolerable, que se le conoce como factor precipitador. Como cuando se dice la gota que colma el vaso.

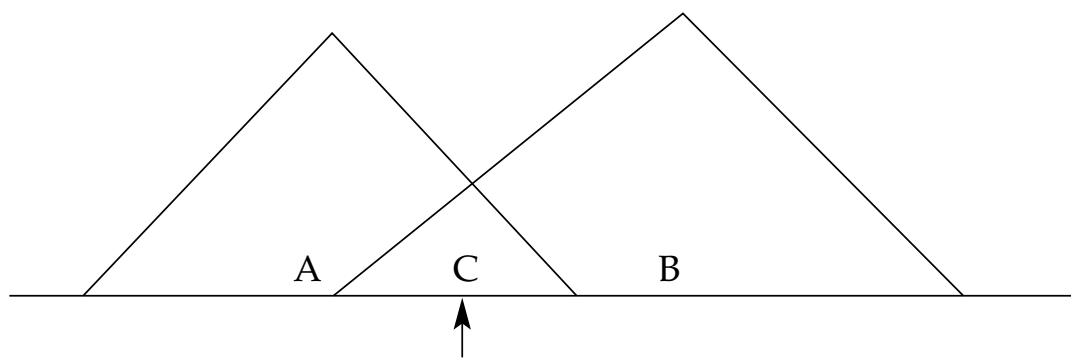

En el gráfico anterior se observa una zona donde coexisten dos sistemas, el A, que es el que ya caduca y el B, que constituye lo

36 Pockran (1964). 
nuevo. La zona, marcada como C, constituye la crisis en sí. Allí se observa lo que afirma Pockran, pues cuando B comienza a nacer, no hay aún crisis, la cual «estalla» como tal, cuando ninguno de los dos sistemas en pugna impera. Si bien en el gráfico es sólo un punto o una línea transversal (flecha) que coincide en el pináculo de la pirámide $C$, en términos temporales puede significar semanas, meses y hasta años.

¿Cuándo, por ejemplo, comenzó la crisis del medio oriente? Pregunta que sólo un experto de la región puede responder. ¿No es mejor hablar de diferentes crisis por país? Esto es lo que afirman ciertos entendidos. Pero es indudable que en estos países los sistemas políticos caducaron. No quiero avanzar más consideraciones en este aspecto, ya que ello escapa a este análisis, pero es importante observar que lo que está ocurriendo hasta hoy en esos países son crisis y no revoluciones. Y es que todo cambio se tiende a calificarlo inmediatamente de revolución, independientemente del hecho que haya un poder central que controle, como si un cambio fuera un paso de testigo de un corredor a otro en una competencia. Así ha ocurrido en la Venezuela de hoy, donde se habla de revolución como si efectivamente se estuviera dando una transformación estructural con la ocurrencia de acciones destructivas del aparato productivo, acciones que, aparte de desmantelar organizaciones, no han dado lugar al surgimiento real de otras de nuevo cuño.

Sobre el caso de Venezuela, que es el que nos interesa vitalmente, si es posible lanzar algunas hipótesis:

- Se supone que la crisis del modelo de crecimiento amparado por el Pacto de Punto Fijo, ${ }^{37}$ se inició en 27 de febrero de 1986, cuando se reconoció la falsa base financiera del sistema que había resplandecido durante el primer gobierno de Carlos Andrés Pérez. Aunque también se puede afirmar que tal viernes negro en el gobierno de Luis Herrera Campins (1986) tenía ya sus antecedentes, o sea, que las élites del momento tenían ya

37 Pacto firmado el 13 de de octubre de 1958 mediante el cual los partidos Acción Democrática, Copei y URD se comprometían a darle un elevado tono al debate electoral y a respetar y hacer respetar el resultado de las elecciones. 
información de lo que estaba sucediendo, pero no actuaron porque esa es una de las características de las crisis, que, si bien ya se evidencian, casi nadie las ve o quiere ver.

- Podría también decirse que el segundo gobierno de Carlos Andrés Pérez constituyó un intento de responder a la crisis ya iniciada, pero que tal intento enfrentó tantos intereses, que la reacción originó un vacío de poder.

- El régimen que surge el 98 como una alianza de izquierdas y derechas para resolver la crisis, se convierte inmediatamente en un enfoque distinto de la misma, por el cual Hugo Chávez y su gente se asumen como sus gestores en busca de su nuevo modelo e inician su «revolución». ${ }^{38}$

Pero tal revolución no ha ocurrido, este es el hecho que interesa. Y no ha ocurrido porque no se ha producido un cambio de sistema. Hasta podría decirse que el viejo sistema Estado Social predomina sustancialmente. $Y$ tal situación plantea una lectura no tan pregonada de la crisis que vivimos. Tal lectura dicta lo siguiente: El sistema A no ha desaparecido y el B se ha quedado hasta ahora en rótulos, consignas, publicidad, aparatos políticos inoperantes y unas bases sociales minadas por la corruptela, la anarquía y el centralismo. Y por temor a las poblaciones urbanas, el régimen ha permitido que continúe la dinámica capitalista, como un ilusionista, mientras sigue intentando montar el sistema B. Lo que planteo es: ¿No será que este sistema $B$ que pretende el régimen no ha dejado de ser un sistema $C$, o sea, la transición crítica hacia un auténtico sistema B?

Este último planteo es muy importante para los gremios productivos venezolanos en este momento, ya que, en la medida en la cual logren reconstruir espacios de innovación productiva, en

38 Con respecto al factor precipitador mencionado antes, el gobierno de Chávez ha demostrado un manejo consciente y deliberado de la crisis que lo llevó al poder, al punto que, según los analistas, cuenta con una «sala situacional», que pudiera ser homologada a un War Room. Al respecto, puede revisarse este concepto en http:// www.paginasprodigy.com/dchong/centrodemando.htm (Centro de Mando), donde se encontrarán comentados autores como el citado Alfred Pockran y Lewis Bornheim. Este último se refiere a la adición de un factor que hace la crisis intolerable, algo que el régimen chavista muestra conocer y manejar en su provecho, hasta ahora. 
esa medida estarán dándole piso social y económico a un verdadero sistema B en esta crisis, sin dejar, por supuesto, de tomar en cuenta el proceso político y su dinámica por demás compleja y decisiva en la crisis.

\section{XII EL NUEVO SISTEMA SOCIAL}

En Venezuela los partidos políticos de oposición han diseñado un mecanismo para seleccionar quien será el candidato de la Mesa de la Unidad opositora en 2012. Algunos critican esto y claman por un Proyecto de País, antes que pensar en candidaturas. ¿Por qué se habla ahora de Proyecto de País y no de Programa de Gobierno? Este requerimiento podría atribuirse a la percepción que se tiene de la necesidad de cambiar de modelo y eso parece apropiado, más aún si tomamos en cuenta el hecho ya señalado de que el actual régimen no representa un nuevo sistema y que él es la expresión final de la crisis iniciada en 1986.

Pero persiste el mismo problema que ya veníamos arrastrando desde el inicio de la democracia venezolana en la mitad del siglo pasado: Colocar al Estado como gestor del desarrollo, error de enfoque y hasta de concepto de lo que es el desarrollo, ya que el Estado no tiene capacidad para pensar a la sociedad como un todo, como no la tiene nadie.

Si el Estado no está capacitado para elaborar tal Proyecto País, el desafío se nos presenta de otra manera: ......el problema económico fundamental no es de naturaleza técnica ni de maximización de una función objetiva "conocida», sometida a restricciones también "conocidas», sino que, por el contrario, es estrictamente económico: surge cuando los fines y los medios son muchos, compiten entre sí, el conocimiento en cuanto a los mismos no está dado, sino que se encuentra disperso en la mente de innumerables seres humanos que constantemente lo están creando y generando exnovo y, por tanto, ni siquiera se pueden conocer todas las posibilidades y alternativas existentes, ni la intensidad relativa con que se quiere perseguir cada una de ellas. ${ }^{39} \mathrm{Y}$ acá se

39 Huerta de Soto (1994), p. 35. 
fundamenta mi propuesta de crear espacios sociales de innovación y emprendimiento agenciados por unos gremios productivos renovados en su relación con el tejido social, donde toma sentido la función empresarial: Para los austriacos, en un sentido general o amplio, la función empresarial coincide con la acción humana misma. En este sentido podría afirmarse que ejerce la función empresarial cualquier persona que actúa para modificar el presente y conseguir sus objetivos en el futuro. ${ }^{40} \mathrm{Y}$ no se trata, para mi propuesta, que los empresarios venezolanos elaboren el tal Proyecto País, por ello aludo a los espacios sociales como ámbitos de acción de los agentes económicos, pero de una acción motivadora, promotora y estimulante de la tendencia humana a la innovación y el emprendimiento en busca del beneficio personal. Y esta acción, a sabiendas que se ha de desarrollar en un proceso crítico sin modelo nuevo definido en la realidad concreta, es y ha de constituirse en una red social y privada (nunca pública) que, por ser lo único concreto y positivo que se haga (además de lo productivo en sí), puede ir fraguando un material básico que funcionará como un piso firme para el nuevo sistema que funcione como salida a la crisis, un sistema, por cierto, eminentemente liberal sin ningún tutelaje del Estado ni instancia superior alguna.

La función empresarial, en un sentido estricto, consiste básicamente en descubrir y apreciar (prehendo) las oportunidades de alcanzar algún fin $o$, si se prefiere, de lograr alguna ganancia o beneficio, que se presentan en el entorno, actuando en consecuencia para aprovecharlas. ${ }^{41}$ Esta precisión de Huerta Soto nos confirma esa perspicacia empresarial, esa vista y mirada muy aguda que alcanza mucho y que le permite, de acuerdo a mi propuesta, ejercer una atención y vigilancia en el espacio social donde actúa, con miras a estimular el emprendimiento, allí donde se exprese en los pequeños intentos de cualquier poblador. Es de insistir que se trata de promover acciones individuales fuera de toda idea colectiva, utilizando el concepto de comunidad, ya que el mismo tiene tradición en Venezuela, gracias a los programas de desarrollo de la comunidad desarrollados desde los años sesenta. En la medida en la

40 Op. cit., p. 38.

41 Op. cit., p. 39. 
cual la innovación y el emprendimiento se van haciendo práctica social, se logra sentar las bases para el nuevo sistema a levantar, haciéndolo de esta manera, desde lo productivo y no desde los imperativos de un Estado interventor. Por ello, cuando se habla de un Proyecto de País no se dice nada sino se le remite a la acción cotidiana de la propia Sociedad, acción para la cual el Estado - el que ha de sobrevenir- solo debe aportar seguridad jurídica y garantías a la libertad individual y a su resultado, visto en bienes y servicios privados.

Pero es necesario reconocer que para desmontar a un Estado financiado por el petróleo de su sitial preponderante, hay que comenzar a fortalecer e incrementar la dinámica de los procesos de cooperación social ${ }^{42}$ impulsados por la empresarialidad, para lo cual, estoy proponiendo trabajar los espacios sociales concernidos por esa empresarialidad, pero sin admitir ni permitir tutelaje alguno por parte del Estado ni tampoco por parte de las empresas que agencien esta búsqueda, ya que ello sería negar la libertad como condición esencial de la acción humana. Pretender esto, sin embargo, frente a un Estado dueño de una fuente de ingresos descomunal, luce, en principio, como un desafío inalcanzable. Pero no es así. Paradójicamente, el hecho que el actual régimen venezolano haya desantedido buena parte de los aparatos tradicionales del Estado en áreas básicas (salud, educación, vivienda, cultura), deja a la sociedad inerme, pues la estructura sociopolítica que se ha levantado para suplir tales servicios, empleando para ello a la estatal petrolera (PDVSA) ${ }^{43}$ como financiadora de programas alimentarios, educativos y de salud (misiones), no ha logrado efectivamente sus objetivos, debido a la ineficiencia de toda esa inversión social, ya que la misma se vierte en burocracias de todo nivel en cada sector. El desempleo disfrazado en la economía informal cunde por todo el país, los egresados de los centros educativos del régimen carecen de reconocimiento en el mercado laboral por su improvisada, ideologizada y deficiente formación, los programas de importación alimentaria presentan alarmantes niveles de corrupción, las expropiaciones de empresas

42 Concepto tomado de Huerta de Soto (2007), pp. 24-25.

43 Petróleos de Venezuela, S.A. 
ganaderas y agrícolas ha semidestruido la capacidad productiva nacional, la industria metalúrgica nacionalizada arroja pérdidas irrecuperables y se le niegan sus contratos colectivos a los trabajadores, persiguiendo y encarcelando sus dirigentes (actualmente se calculan en 250), el movimiento cooperativo se hundió en el fracaso bajo la inspiración socialista, al igual que las «empresas» comunales para servicios comunitarios. El régimen ha destruido la red hospitalaria. ${ }^{4}$

En tal situación, con unos aparatos de Estado paralelos e ineficientes en ambas líneas (la tradicional y la socialista), la inversión social se dilapida sin lograr servir eficazmente a la población, más aún la de bajos recursos. El vacío productivo resultante es suplido por caudales de importación en bienes y servicios, cuyo subsidio van minando las reservas del Estado y creando en la población una necesidad imperiosa de lograr ingresos suplementarios a través de actividades informales colocadas en el final de las cadenas de bienes de todo tipo que entran por la economía de puertos creada.

En medio de este panorama, se presenta justamente un terreno fértil para estimular la empresarialidad desde unos gremios productivos dispuestos a liderizarla como tendencia natural de la acción humana. Esta es la propuesta que vengo presentando, no como una idealización del mercado, sino como la creación de nichos productivos a lo largo de las comunidades, suburbios y urbanizaciones que logren expandir una visión social del liberalismo económico que supla el vacío productivo de la ideología comunal y socialista y vaya así fertilizando el surgimiento de un nuevo sistema como resolución de la crisis (el sistema B graficado en el punto XI).

¿Cuál sería el papel del Estado en ese nuevo sistema? La primera función a desempeñar por el Estado es la de garantizar y asegurar la existencia y funcionamiento efectivo de un sistema judicial que asegure la igualdad de cada ciudadano ante la ley. Tal sistema judicial debe también actuar para proteger al ciudadano de abusos de poder por parte de cualquier instancia del Estado.

44 Ver la entrevista a Rafael Muci-Mendoza, neuro oftalmólogo, en el periódico venezolano El Universal del 20/03/2011, p. 4-2. 
Con respecto al cuerpo de leyes, estas deben garantizar el derecho a la propiedad y la libertad individual dentro del respeto mutuo. No pretendo en momento alguno definir ese Estado, tarea imposible por lo que ella supone en información (como ya hemos visto y veremos más adelante), pero si advertir que la igualdad de todos y cada uno ante la ley, excluye, por nocivo, el concepto de justicia social, que, como hemos visto ya, da lugar a la implantación del Estado Social o benefactor y su actual perversión, la del Estado Comunal o Socialismo del Siglo XXI.

La ventaja que veo con la realización de una acción empresarial como la propuesta, es que se estaría fortaleciendo a la sociedad, es decir, a la base de todos los sistemas que se vayan conformando (legal, judicial, de seguridad, sanitario), teniendo todos como principio la libertad de emprendimiento y respetando permanentemente su dinámica, donde los sistemas se vayan adaptando a ella, por lo cual es el Estado el que es definido y limitado por la Sociedad y nunca al contrario.

Toca a la sociología continuar con ahínco una serie de investigaciones sobre tal complejo dinámico y darle sustancia a esa base de lo que sería el Sistema $B$ en el caso venezolano, tarea para la cual es necesario colaborar con la acción empresarial propuesta de crear auténticos espacios sociales donde se ejerza sin intervencionismo alguno la acción natural de los individuos hacia el emprendimiento, la innovación, la competencia y el reajuste social.

¿Qué decir, a fin de cuentas, del tan deseado Proyecto de País que se está buscando? No creo que se trate de intelectualizar mucho al respecto, bajo el entendido que aquel que pretenda, «mejorar» u organizar una determinada área de la vida social, carecerá del enorme volumen de información práctica y dispersa que se encuentra distribuida en la mente de los miles de individuos que hayan de sufrir sus órdenes (y ello por razones de capacidad de comprensión, volumen $y$, sobre todo, dado el carácter tácito e inarticulable, y por tanto esencialmente no transmisible, del tipo de conocimiento práctico relevante para la vida en sociedad)..$^{45} \mathrm{Si}$ hay algo en lo que si tienen que enfrascarse los políticos que quieren asumir el poder del Estado al

45 Huerta Soto (1994), p. 93. 
cesar el régimen actual venezolano, es en cómo dejar de pensar como hombres de Estado, en términos del Estado Social, para convertirse en auténticos servidores públicos garantes de la ley y la libertad individual, para lo cual deben comenzar a prepararse para quitarle funciones económicas al Estado y hacer desaparecer el nefasto intervencionismo creado por ellos mismos en su afán de justicia social.

\section{XIII \\ A MANERA DE CONCLUSIÓN}

En el actual panorama político que impera en Venezuela, esta propuesta como señalé en la Presentación, es como la botella que lanza un náufrago al mar desde su isla solitaria, preguntándome a fin de cuentas sino es mi propio país el náufrago.

La crisis que vivimos es realmente societal porque es una crisis de crecimiento que atañe a todo el conglomerado venezolano sin distingo alguno y en todos los órdenes de la vida. Mi esperanza es que podamos tomar conciencia de la crisis que vivimos en términos humanos por nuestros propios errores, primera condición para reconocer la necesidad de trazar y excavar una ruta nueva de verdad desde hoy mismo, como dice el adagio, hasta el camino más largo comienza con un primer paso. Pero ese primer paso tiene que ser firme, haciendo huella en el terreno, y con una orientación clara sobre lo que requerimos. Y si algo requerimos es abandonar esta ruta falsamente social que hemos traído durante más de ochenta años, marcada por el surgimiento de un Estado que motivó, incitó y promulgó una sociedad rentista.

Todo programa o proyecto que se diseñe bajo esta óptica social del Estado benefactor o interventor está concebido para perpetuar el status quo opresor. La inercia es excesiva, ni aún en plena crisis se deja de pensar en la oposición desde la óptica del Estado, desde la cual la Sociedad será conducida por un camino preconcebido.

Ciertamente, la Sociedad venezolana tiene asociaciones civiles que han luchado desde hace años por el desarrollo social verdadero, aquel que se agencia desde la propia sociedad. A sabiendas 
de que este trabajo va dando sus frutos, el régimen ha prohibido el financiamiento externo de esas asociaciones (llamadas organizaciones no gubernamentales u ong por distinguirlas justamente del Estado). En las ciencias sociales, esta prohibición propia de todo totalitarismo, ha tenido consecuencias negativas, pues tales asociaciones contrataban a investigadores y consultores para llevar adelante sus programas y proyectos, lo cual permitía a sociólogos, antropólogos, trabajadores sociales, psicólogos, economistas, etc. mantenerse activos como profesionales libres. Al perder una fuente importante de su financiamiento, muchas asociaciones civiles tuvieron que cerrarse y otras reducirse al mínimo, con lo cual todas estas profesiones quedaron a merced de la contratación del Estado y, por tratarse de un Estado con tendencia totalitaria, tales científicos sociales jamás serán contratados con la libertad que requieren para ejercer sus profesiones, motivo por el cual muchos de ellos han pasado a ejercer la economía informal pues ¿dónde van a acudir para prestar sus servicios? La única fuente de empleo digno de sus saberes que les queda - aparte de las universidades ahogadas económicamente por el gobierno- es la empresa privada, la misma que viene siendo destruida también por el régimen.

Es aquí donde toca a los empresarios convertirse en gestores de una sociedad de emprendedores, lo cual supone invertir en, además del beneficio económico (por supuesto), en el beneficio social. Empresas, universidades, centros de investigación, academias, gremios productivos y profesionales, asociaciones civiles, fundaciones y consultores e investigadores independientes deben reencontrarse en esta tarea, la cual es mucho más amplia de lo que yo vengo de exponer, por lo que exige el concurso de variadas disciplinas, vocaciones y voluntades, ya que, como ya vimos, busca abonar un terreno social fértil para el cambio de sistema que requerimos con urgencia para salir de la crisis y hacerla entonces oportuna. Se trata de actuar en términos sociales ya, hoy mismo, sin esperar los plazos políticos. Más aún, se trata de hacerlo justamente antes de que el régimen caiga, para evitar que se instale de nuevo un Estado Social que nos conduzca, de nuevo, a otra crisis como la que estamos viviendo. 


\section{REFERENCIAS BIBLIOGRÁFICAS}

Bolman, L.Q. y Deal, T.E. (1995): Organización y Liderazgo, USA, Addison-Wesley Iberoamericana, S.A.

HABERMAS, Jürgen (1988): Ensayos politicos, Barcelona, Ediciones Península, pp. 113-134.

Huerta De Soto, J. (1994): Nuevos Estudios de Economía Política, España, Unión Editorial.

- (2007): «Liberalismo versus Anarcocapitalismo», Procesos de Mercado, Volumen IV, Número 2, otoño, pp. 13-32.

Lefort, C. (1983): La Imagen del Cuerpo y el Totalitarismo Letras libres. Lo último del autor. Hemeroteca, Marzo, pp. 14-19. http: / / www.letraslibres.com/index.php?sec=22\&autor= Claude\%20Lefort

PockRAN, A. (1964): Culture, Crisis and Change. Chicago, USA, University of Chicago Press. 